Primljeno: 11. 8. 2020.

Prihvaćeno za štampu: 28. 10. 2020.

\author{
Dr. sc. Sulejman Topoljak, redovni profesor \\ Univerzitet u Bihaću \\ Islamski pedagoški fakultet \\ E-mail: sulejman.topoljak@hotmail.com
}

\title{
PRAVNI STATUS IZGUBLJENE IMOVINE U ISLAMU
}

\section{Sažetak}

Ova studija, u okvirima uturdenih pravila naučne elaboracije, nastoji istražiti dva osnovna cilja. Prvi je da se, implicite, istakne univerzalnost $i$ dosljednost islamskog prava čija je glavna odlika njegova utemeljenost na etici i moralu čjje principe ono štiti svojim pravnim normama $i$ sankecijama. A drugi cilj jest da na isti način istakne va:̌nost $i$ zaštićnost imovine $u$ islamu, po kome ona nije cilj, niti glavna vrijednost $u$ covjekovom rivot, nego samo sredstvo koje je neophodno posjedovati $i$ upotrijebiti pri realizacije sistema prioriteta $i$ osnovnih ciljeva radi kojih je Allah stvorio covjeka $u$ ovom kosmosu. Po filozofiji islama svi ljudi su braća, stoga podjednako imaju pravo na prirodne resurse, kao i na ljudsko dostojanstvo. Radi toga su obavezni štititi ljudske vrijednosti i kosmickei sistem kojeg je Bog postavio, te se suprotstaviti svima onima koji te principe narušavaju $i$ devalviraju, ili ih ignoriraju i uništavaju. Filozofija imovine $u$ islamu definira percepciju i viziju njene intencije u životima muslimana. Ona je susta suprotnost istoj u savremenoj ideologiji pa su neminovne $i$ rąlicite njihove posljedice, kako na řivot i odnose ljudi prema njoj, tako i na meduljudske odnose, opíenito. Onaj ko to ne poznaje, ne može ni shvatiti, niti razumjeti dvije suprotne civilizacije koje su proistekle iq rąlicite dvije rivivotne filozofije.

Ključne riječi: imovina, iəgubljene stvari, predmeti, そ̌ivotinje, propisi, pravne škole, mezhbebi, pravnici. 


\section{Uvod}

Materijalizam, individualizam, urbanizam i utilitarizam se jednim imenom mogu nazvati ideologijom savremene civilizacije koja dominira svijetom danas. Njihova osnovna dogma jest materija, profit $i$ lični interesi, prije svega ostalog. Svojim blještavim materijalnim sjajem i korumpiranim medijima svijetu plasiraju nerealan, nestvaran, lažan, razuzdan i raskošan život u kojem su univerzalne ljudske vrijednosti devalvirane ili skoro uništene, a sistem njihove prioritetnosti na koncu potpune poremećenosti. Misionari nove ideologije po svaku cijenu nastoje ovladati svjetskim materijalnim dobrima i postati savremeni robovlasnici, te sve ljude potčiniti svojim ambicijama, željama, vizijama i percepciji svijeta te odnose u njemu kako bi ih učinili savremenim robovima čijim će se mislima, željama, osjećajima, umovima, snagom i voljom upravljati na daljinu s ciljem uspostavljanja novog faraonskog sistema u svijetu. U njemu bi se svi besprijekorno pokoravali volji robovlasnika i protagonista nove ideologije i novog svjetskog poretka. Na tom putu se nemilosrdno i bezobzirno ruše svi univerzalni principi i načela, ljudska prava, slobode i pravda. U savremenoj ideologiji samo onaj ko ima materijalnu moć i snagu ima pravo i na život. Onaj ko ima pravo na život ima pravo raditi šta hoće i kako hoće - oduzimati drugima živote, uzurpirati imovinu, postavljati zakone i pravila, ali isključivo radi svojih uskih materijalnih i utilitarističkih ciljeva. Slabi i obespravljeni po tim pravilima i viziji nemaju pravo da žive, jer su ekonomska šteta i neisplativost pa ih se treba po svaku cijenu riješiti. Njihova vjera, život, čast, sloboda $\mathrm{i}$ imovina su nezaštićeni u svakom smislu, posebno ako predstavljaju opasnost ili smetnju interesima jakih i snažnih.

\section{Pojam i osnovne naznake}

Izgubljena imovina (stvar) u arapskom jeziku se naziva el-lukata.

U islamsko-pravnoj terminologiji lukatom - izgubljenom stvari se smatra vrijedna imovina - mal muhterem koja se nađe na mjestu na kojem se obično ona ne čuva - gajre muhriz, a čiji vlasnik je nepoznat onom ko ga nađe ${ }^{1}$.

\footnotetext{
1 San'ani, Subulus-selam, 3/120.
} 
Dakle, da bi se neka imovina smatrala izgubljenom po najprihvatljivijoj definiciji mora ispuniti određene preduslove od kojih su:

- da bude nečije vlasništvo, što implicira da nikom nije dozvoljeno raspolagati njome bez dozvole njenog vlasnika,

- da se ne uzme sa mjesta na kojem se obično drži i čuva imovina i

- da joj vlasnik bude nepoznat ili da ne bude mubah - ničija imovina.

Rad smo podijelili na dva dijela. U prvom dijelu se govori o pravnom statusu izgubljenih stvari, a u drugom o pravnom statusu izgubljenih životinja. Bilo bi prikladno ovdje govoriti i o pravnom statusu nestalih ljudi, ali nam predviđen prostor $\mathrm{u}$ Zborniku to ne dozvoljava pa se nadamo, ako Allah dozvoli, da ćemo nekom drugom prilikom, ili na nekom drugom mjestu, govoriti o ovoj veoma aktulenoj temi danas.

\section{Prvi dio}

\section{Pravni status izgubljene imovine - stvari ili predmeta}

Islamski pravnici smatraju da bi neka imovina imala pravni status izgubljena imetka općenito mora ispuniti tri osnovna elementa - rukna:

Prvi - Uzimanje stvari ili predmeta el-lekt;

Drugi - Uzimatelj tj. onaj koji je uzme el-multekit;

Treći - Izgubljena stvar el-melkut.

U nastavku studije ćemo se osvrnuti na navedene elemente i ukratko ih pojasniti.

\section{Prvi rukn: uzimanje el-lekt}

Izgubljena stvar da bi dobila status izgubljene imovine mora se, nakon što se nađe, uzeti s mjesta gdje se našla. Uzimanje takve imovine $u$ startu u islamskom pravu ima status emaneta i raspolaganja - korištenja, a u krajnjem ishodu može dobiti i status zaposjedanja i vlasništva. 


\section{Šerijatski stav uzimanja izgubljeno imovine}

O statusu uzimanja izgubljene imovine islamski pravnici nemaju jedinstven stav.

Hanefijski i šafijski pravnici smatraju da je takvu imovinu poželjno mustehab uzeti, a malikijski i hanbelijski da je mekruh - pokuđeno. $^{2}$

Ukoliko se detaljno prouče sve dileme i mišljenja navedenih pravnih škola o statusu uzimanja izgubljene imovine, može se konstatovati sljedeće: ${ }^{3}$

a) da njeno uzimanje može biti vadžib - obavezno, onda kada postoji bojazan da bi se ona mogla uništiti ili nestati, ili kada se pretpostavi da je niko drugi neće naći osim onog koji ju je već našao;

b) da njeno uzimanje može biti mendub - preporučeno, onda kada ne postoji bojazan da će se uništiti ili izgubiti i kada onaj ko je pronađe bude siguran da će biti u stanju oglašavati njen pronalazak do pronalaska njena vlasnika;

c) da njeno uzimanje može biti haram - zabranjeno, onda kada se uzme s namjerom njena prisvajanja i nevraćanja njenom vlasniku;

d) da njeno uzimanje može biti mekruh - pokuđeno, onda kada onaj ko je nađe ne bude siguran da će je vratiti njenom vlasniku;

e) da njeno uzimanje može biti mubah - dozvoljeno, onda kada njeno uzimanje i neuzimanje imaju iste posljedice po nju.

Navedeno potvrđuje i Ibn Hadžer u sljedećem citatu: „Islamski učenjaci smatraju da status uzimanja izgubljene stvari ne treba generalizirati, nego se on razlikuje od nijeta osobe i od situacije do situacije. Kada onaj koji nađe izgubljenu stvar, bude uvjeren da ju je bolje uzeti nego ostaviti, onda će njeno uzimanje biti obavezno ili poželjno. A kada bude uvjeren da ju je bolje ostaviti nego uzeti, onda će njeno uzimanje biti zabranjeno ili pokuđeno. Ukoliko ne bude moguće preferirati između njena uzimanja ili ostavljanja, onda će njeno uzimanje biti dozvoljeno ${ }^{4}$, .

2 Ibn Abdulberr, El-Istizkar, 22/326.

${ }^{3}$ En-Nevevi, El-Medžmu'u, 6/137.

${ }^{4}$ Ibn Hadžer, Fethul-Bari, 5/111. 


\section{Pravni status svjedoka u instituciji izgubljene imovine}

Postavlja se pitanje da li se pri preuzimanju izgubljene imovine uslovljava svjedočenjem i svjedocima? Po ovom pitanju nemamo jedinstven stav islamskih pravnika.

Zahirije - literalisti, neki šafijski pravnici, Ševkani i San'ani smatraju da je obaveza - vadžib da preuzimanje izgubljene stvari potvrde i svjedoci. $^{5}$

Svoje mišljenje potkrepljuju hadisom kojeg prenosi Ijad b. Himar u kom se kaže: „Ko nađe izgubljenu stvar, neka mu to posvjedoči jedan pravedan musliman." U drugoj predaji stoji da to trebaju posvjedočiti dva pravedna i poštena muslimana da je pronalazač neće ni sakriti, a niti prisvojiti, te da kada se javi njen vlasnik da će mu je vratiti. Ukoliko se on ne pojavi, onda je to Allahov imetak koga On daje kome hoće."“6

Malikijski, neki šafijski i hanbelijski pravnici smatraju da je preporučeno preuzetu pronađenu stvar verifikovati svjedočenjem svjedoka. $^{7}$

Oni koji smatraju da je preuzetu izgubljenu stvar neophodno potvrditi sa svjedocima to uslovljavaju radi sprečavanja pronevjere i utaje izgubljene imovine od strane onog koji je uzme, kao i zbog toga da se ona nakon njegove smrti ne prisvoji od strane nasljednika, smatrajući je dio ostavštine umrlog kako bi se na taj način zaštitilo pravo njena vlasnika. Stoga je neophodno imati svjedoke koji će potvrditi da ona nije dio nasljedstva. A protagonisti drugog stava to preventivno preporučuju radi neželjenih posljedica.

\section{Na koji način se vrši svjedočenje?}

Islamski pravnici navode dva načina svjedočenja:

5 En-Nevevi, El-Medžmu'u, 6/137, Ibn Hazm, El-Muhalla, 5/257, Ševkani, Nejlulevtar, 5/339, San'ani, Subulus-selam, 3/119.

6 Ahmed, Musned, 4/266, Ebu Davud, Sunen, 2/335, br.1709, Ibn Madže, Sunen, 2/837, br. 2505.

${ }^{7}$ Ibn Hazm, El-Muhalla, 5/257, Ševkani, Nejlul-evtar, 5/339, San'ani, Subulus-selam, $3 / 119$. 
Prvi - da nakon što se nađe izgubljena stvar pronalazač otkrije njen pronalazak, a potom to posvjedoči jedan ili više povjerljivih ljudi, ne opisujući je ni detaljno, niti načelno, kako bi se spriječilo njeno bespravno prisvajanje.

Drugi - da nakon priznanja pronalaska izgubljene imovine svjedoci posvjedoče i potvrde da je taj i taj našao izgubljenu stvar, opisujući je pritom detaljno kako bi se na taj način ona mogla izdvojiti iz nasljedstva.

Neki šafijski pravnici smatraju da je najbolji način svjedočenja onaj $u$ kom se ne bi spominjali svi detalji pronađene imovine - stvari, nego samo oni koji su najbitniji. Imam Nevevi smatra da je ovaj način najispravniji. ${ }^{8}$

Treba napomenuti da se ovi propisi o izgubljenoj imovini, koje smo dosad spomenuli, odnose samo na predmete i stvari, a ne i na izgubljene životinje.

\section{Status izgubljenih stvari u Mekki}

Postoje vjerodostojni pravni tekstovi po kojima je zabranjeno uzimanje izgubljenih stvari koje hadžije izgube u Mekki, ili koje se općenito izgube u Mekki.

Ebu Hurejre prenosi da je Poslanik, a.s., rekao: „Neka niko ništa ne uzima od onoga što je izgubljeno u Mekki, osim onog koji to želi oglasiti. "

U drugom hadisu kojeg prenosi Abdurrahman b. Osman Et-Tejmimi se kaže da je Allahov Poslanik, a.s., zabranio uzimanje stvari koje hadžije izgube u Mekki. ${ }^{10}$

Islamski pravnicu smatraju da se navedene zabrane uzimanja izgubljenih stvari u hadisima odnose samo na one koji ih uzmu da bi ih sebi prisvojili, ali ne i na one koji ih žele vratiti njihovim vlasnicima.

\footnotetext{
8 Ševkani, Nejlul-evtar 5/339.

9 Ibn Hadžer, Fethul-Bari, 5/104, br. hadisa 2434, Nevevi, Šerhu Sahihi Muslim, 9/126.

${ }^{10}$ Muslim, Sahih, br. hadisa 1724, Ebu Davud, Sunen, br. hadisa 1719.
} 
Ovakav stav zastupaju Zahirije - literalisti, neki šafijski i hanbelijski pravnici i Ševkani. ${ }^{11}$

Hanefijski pravnici, neki šafijski i hanbelijski smatraju da nema nikakve razlike između statusa uzimanja izgubljene stvari u Mekki ili na bilo kojem drugom mjestu u svijetu, jer tuđi imetak je svugdje tuđi imetak koji je u takvom stanju izložen uništenju pa ga treba uzeti i zaštititi ga. ${ }^{12}$

Smatramo da je mišljenje hanefijskih pravnika po ovom pitanju prihvatljivije, posebno u današnje vrijeme kada je iman u srcima muslimana u velikoj mjeri oslabio. Isto tako, kada se pomno prouče obrazloženja prvog mišljenja, zapazit će se da se u biti i intenciji slažu s drugim mišljenjem te da među njima nema suštinske razlike. A općepoznato je da se u šerijatu preferira bit i suština nad formom i literalnim značenjima.

\section{Drugi rukn: Pronalazač - el-multekit}

Da bi postupak preuzimanja pronađene imovine mogao proizvesti pravne posljedice neophodno je da se ono desi od pronalazača koji mora ispuniti određene uvjete. Obično se uslovljavaju isti uvjeti koji se uslovljavaju i za povjerioca. Dakle, mora posjedovati potpunu poslovnu sposobnost.

O uvjetima koji su neophodni da se nađu kod pronalazača izgubljene imovine imam Nevevi je rekao: „(...) on treba da bude slobodan, musliman, punoljetan i pošten."13

Međutim, neki islamski pravnici dozvoljavaju i nemuslimanu preuzimanje izgubljene imovine ukoliko posjeduje potpunu poslovnu sposobnost. ${ }^{14}$

Neki pravnici dozvoljavaju i licima koja nemaju potpunu poslovnu sposobnost preuzimanje izgubljene imovinu poput djece, maloumnih

11 Ibn Hazm, El-Muhalla, 5/258, Nevevi, El-Medžmu', 16/134, Ibn Kudame, ElMugni, 6/360, Ševkani, Nejlul-evtar, 5/344.

${ }^{12}$ Ibn Abidin, Hašije, 6/437, Ibn Kudame, El-Mugni, 6/389.

13 Nevevi, El-Medžmu'u, 16/134.

14 Ibn Kudame, El-Mugni, 6/360, Nevevi, El-Medžmu'u, 16/176. 
itd., smatrajući da je ono validno analogno na njihovo zaposjedanje mubah imovine.

Smatramo da je ovo mišljenje neprihvatljivo i oprečno općim pravilima i intencijama šerijata, jer kod zaposjedanja mubah imovine se uslovljava nijet za njeno posjedovanje. U protivnom, neće biti legalno niti validno, a nijednom od navedenih lica nijet nije pravno validan. Također, odobravanje uzimanja izgubljene imovine se dozvoljava, prije svega, radi njene zaštite od uništenja i propadanja, a čega navedena lica nisu i ne mogu biti potpuno ili nikako svjesna.

Sve navedeno, neki šafijskih i hanbelijskih pravnici su imali na umu pa su istakli da ukoliko dijete ili luđak nađu izgubljenu imovinu, njihovi staratelji su obavezni uzeti je od njih radi zaštite i oglašavanja te njena povrata vlasnicima. $^{15}$

Isto tako, hanefijski pravnici smatraju da je uzimanje izgubljene stvari od strane djeteta dozvoljeno, dok to ne dozvoljavaju luđaku. ${ }^{16}$

\section{Status izgubljene stvari nađene od strane više osoba}

Po ovom pitanju se mogu pretpostaviti sljedeće situacije:

1. - Da dvojica nađu izgubljenu imovinu pa se jedan od njih odrekne svoga pravo na nju u korist drugog. On ne bi zbog toga izgubio svoje pravo na pronađenu imovinu. ${ }^{17}$

2. - Da dvojica donesu dokaze na osnovu kojih svako od njih tvrdi da je on, a ne neko drugi našao izgubljenu imovinu, a u isto vrijeme se ne mogne utvrditi ko ju je od njih dvojice prije vidio - našao. Izgubljena imovina će pripasti onom kod koga bude, jer su njegovi dokazi u tom slučaju jači i prihvatljiviji.

3. - Da neko nekome rekne da uzme izgubljenu imovinu kada je vidi, pa je i uzme, pripast će onome koji mu je rekao da je uzme, pod uvjetom da je tako namjeravao onaj koji ju je uzeo. Ali, ukoliko je 9namjeravao

\footnotetext{
15 Nevevi, El-Medžmu'u, 16/173, Ibn Kudame, El-Mugni, 6/386.

16 Ibn Abidin, Hašije, 6/435.

17 Ibn Kudame, El-Mugni, 6/356.
} 
s njenim uzimanjem da pripadne njemu i onome koji mu je rekao da je uzme, pripast će njima dvojici. ${ }^{18}$

4. - Da dvojica u isto vrijeme vide izgubljenu imovinu pa je uzme jedan od njih prije drugoga, ili, ako bi jedan od njih vidio izgubljenu stvar i pokaže je drugom pa je on i uzme, pripast će onom ko je uzme, jer pravo nad izgubljenom stvari ima onaj ko je prvi uzme, a ne onaj ko je prvi vidi kao kod lova. ${ }^{19}$

\section{Treći rukn: Izgubljena stvar - el-melkut}

Pod ovim ruknom se misli na legalnu, po šerijatu, imovinu čiji vlasnik je nepoznat onome ko je pronađe. Izgubljen imetak, kako smo već rekli, može biti hajvan - dalleh, predmet i stvar - lukata. Prema tome, dozvoljen - mubah imetak poput javnih pašnjaka, vode, bisera i ribe $u$ moru itd., ne mogu biti izgubljene stvari, jer nisu ni u čijem vlasništvu.

\section{Nekoliko primjera imovine koja sliči izgubljenom imetku}

Kada neko namjerno ili nenamjerno uzme nečiju stvar, a ostavi svoju, da li bi se ta ostavljena stvar kod onoga od koga je uzeta njegova, smatrala izgubljenom stvari?

Ovdje treba napraviti razliku između nekoliko situacija:

- Ako je neko otuđi nenamjerno, onda će se njegova stvar koju je ostavio smatrati izgubljenom, u protivnom će biti dozvoljeno onom čija je stvar uzeta prodati ostavljenu, i na taj način kompenzirati svoje otuđeno pravo.

- Ukoliko otuđena stvar bude bolja od ostavljene, to će se smatrati dovoljnim dokazom da je namjerno otuđena. Međutim, ako ostavljena stvar bude bolja ili ista od uzete, onda je to dokaz da ona nije otuđena namjerno, pa će imati status izgubljene imovine i nad njom će se primijeniti propisi iste. ${ }^{20}$

\footnotetext{
18 Ibn Kudame, El-Mugni, 6/356.

19 Ibid.

${ }^{20}$ Ibn Kudame, El-Mugni, 6/373.
} 
Ukoliko bi neko ostavio neku životinju na mjesto gdje se obično životinje ostavljaju da dočekaju svoju smrt, pa je neko uzme da je prehrani i spasi od propasti, ona će u tom slučaju pripasti njemu, jer takva vrsta životinja ima status mubah imovine.

U tom smislu Poslanik, a.s., je rekao: „Ko nađe neku životinju čiji je vlasnici ne mogu izdržavati i ostave je, pa je uzme i spasi ona će pripasti njemu." ${ }^{21}$ Ovo je mišljenje hanbelijske pravne škole.

Malikijska i šafijska pravna škola i Ibn Munzir smatraju da životinja pripada njenom vlasniku, a onaj koji je spasi ima status dobročinitelja koji će biti nagrađen za dobro djelo koje je uradio u ime Allaha. ${ }^{22}$

\section{Obaveze onoga koji nađe i uzme izgubljenu imovinu}

Ko uzme izgubljenu imovinu nakon njena pronalaska dužan je sljedeće:

1. - da sačuva njene najizrazitije osobine;

Poslanik, a.s., je naredio onome ko nađe izgubljenu stvar da zapamti sačuva njene osobine pa je rekao: „Zapamti kesu i konac s kojim se vezala."

Ovdje se dakle aludira na posudu, vreću, konac ili poklopac u kojima se ili s kojima se našla izgubljena imovina. ${ }^{23}$ Prema tome, ovaj hadis, implicite, aludira na obavezu pamćenja osobina i sredstava u kojima se našao izgubljeni imetak, izgubljena stvar ili predmet. ${ }^{24}$

Iz hadisa se, također, razumije da je dozvoljeno upoznati se sa svim osobinama koje su neophodne da bi se lakše i preciznije našla i prepoznala izgubljena imovina, kao što su npr. njena vrsta, boja, količina itd., i to sve radi toga da bi se mogla lakše provjeriti tvrdnja i istinitost onih koji će dolaziti i tvrditi da je njihovo vlasništvo. ${ }^{25}$

Hafiz Ibn Hadžer je rekao: „Po pitanju pamćenja osobina izgubljene stvari islamski učenjaci zastupaju dva stava. Prihvatljiviji je onaj koji

\footnotetext{
21 Sahihul džami' br. 6584.

22 Ibn Kudame, El-Mugni, 6/400.

23 Ibid.

${ }^{24}$ Ibn Hadžer, Fethul-Bari, 5/98, Nevevi, Šerhu Sahihi Muslim, 2/159.

${ }^{25}$ Ibn Hadžer, Fethul-Bari, 5/98.
} 
smatra da je to obaveza - vadžib na osnovu hadisa u kojem se to jasno i nedvosmisleno naređuje. “26

Mustehab je po nekim islamskim pravnicima da se zapišu najizrazitije osobine nađene stvari iz bojazni da se ne zaborave i tako oteža proces utvrđivanja njena vlasnika. Ovo mišljenje zastupa imam Ahmed i Nevevi. ${ }^{27}$

2. - da oglašava da je pronašao izgubljen imetak ili imovinu;

Ova obaveza je propisana radi pronalaska izgubljene imovine od strane njena vlasnika.

Oglašavanje treba prilagoditi običaju mjesta u kom živi onaj koji je pronašao takav imetak, te odabrati najefikasnija sredstva putem kojih se može najbrže i najefikasnije realizovati navedeni cilj i intencija.

Hanbelijski pravnici dozvoljavaju da se pri oglašavanju navede vrsta izgubljene imovine kao, naprimjer, zlato ili srebro, a šafijski čak i neka njena svojstva, ali zabranjuju navođenje njenih detalja. Neophodno je pri tome biti veoma oprezan i o svojstvima nađene imovine govoriti $u$ prenesenom smislu ako bude potrebe za tim.

Obaveznost oglašavanja o pronalasku izgubljene imovine je potvrđena u pravnom tekstu u kojem je Poslanik, a.s., rekao: „Oglašavaj njen pronalazak tj. pronalazak izgubljene stvari godinu dana.“ Dužinu perioda oglašavanja pronalaska pronađene stvari spomenutu $u$ hadisu prihvatila je većina islamskih pravnika. ${ }^{28}$

Međutim, treba istaći da postoje i predaje u kojima se zabranjuje uzimanje izgubljenih stvari $\mathrm{s}$ namjerom njihova prisvajanja $i$ neoglašavanja njihova pronalaska.

Muslim od Zejda b. Halida bilježi da je Poslanik, a.s., rekao: „Ko zatvori izgubljenu životinju, uveliko se udaljio od istine sve dok ne oglasi njen pronalazak." 29

\footnotetext{
26 Ibid.

${ }^{27}$ Ibn Kudame, El-Mugni, 6/363, Nevevi, Revdatut-talibin, 4/453.

${ }_{28}$ Nevevi, El-Medžmu, 6/141, Ibn Kudame, El-Mugni, 6/347, San'ani, Subulus-selam, 3/117, Ševkani, Nejlul- evtar, 5/340, Nevevi, Šerhu Sahihi Muslim, 12/22.

${ }^{29}$ Nevevi, Šerhu Sahihi Muslim, 12/28.
} 
Od Džaruda se prenosi da je Poslanik, a.s., rekao: „Izgubljena životinja muslimana je vatra koja prži. “"30

Iz obaveznog oglašavanja pronađene imovine se izuzimaju sljedeći slučajevi:

a) Pronadene stvari za koje se zna da ih njen vlasnik ne traži zbog njihove minorne ili nikakve vrijednosti, ili koje je ostavio i odrekao ih se.

Međutim, neki pravnici smatraju da prvobitni vlasnik ostavljenih ili odbačenih stvari ima pravo na njihov povrat, jer njihovo bacanje ili ostavljanje, po njima, ima samo status dozvole korištenja, ali ne i vlasništva, jer dozvola korištenja nečega ne podrazumijeva i njegovo vlasništvo, što znači da one, na osnovu ovog pravila, nisu ni izašle iz vlasništva njihovog prvobitnog vlasnika, stoga ih on ima pravo povratiti i uzeti. ${ }^{31}$

Hanbelijski pravnici smatraju da su spomenute stvari vlasništvo onoga ko ih pronađe, jer ih se njihov prvobitni vlasnik odrekao. Ovo mišljenje je prihvatljivije i bliže je duhu i intencijama šerijata, te logici stvari.

b) Pronađena stvar s neznatnom materijalnom vrijednosti

Od Enes b. Malik, r.a., se prenosi da je jedne prilike Poslanik, a.s., prošao pored bačene hurme pa je rekao: „Da znam da nije od sadake zekata pojeo bih je.“32

Hadis, implicite, potvrđuje da se pronađene stvari, neznatne i minorne vrijednosti, ne trebaju oglašavati. Ovo je stav šafijskih i hanbelijskih pravnika. $^{33}$

Ebu Davud bilježi od Džabira, r.a., da je rekao: „Allahov Poslanik nam je dozvolio da štap, bič, uže i sl. tome uzmemo kada ih nađemo, te da se koristimo njima." ${ }^{\text {34 }}$

\footnotetext{
30 Tirmizi, Sunen, br.1882, Ahmed, Musned, 5/80 i drugi.

31 Ibn Abidin, Hašije, 6/436.

32 Ibn Hadžer, Fethul-Bari, 5/103, broj hadisa 2431.

33 Ibn Kudame, El-Mugni, 6/351, Nevevi, El-Medžmu', 16/ 146.

34 Ebu Davud, Sunen, broj hadisa 1459.
} 
Međutim, u hadisu kojeg bilježi Ahmed u svom Musnedu od Ja'la b. Murreta se kaže da je Poslanik, a.s., rekao: „Ko nađe neku neznatnu stvar poput užeta, dirhema itd., neka je oglašava tri dana, a ako nađe vredniju od njih neka je oglašava šest dana. “35

Ovaj hadis prenosi i Taberani, ali s dodatkom: „Pa ako se javi njen vlasnik neka mu je preda, u protivnom neka je podijeli na ime sadake."

Međutim, o citiranom hadisu Ševkani je rekao: „U njegovom lancu prenosilaca je Omer b. Abdullah b. Ja'la. Mnogi kritičari hadisa ga smatraju slabim - nepovjerljivim prenosiocem. Ukoliko bi se prihvatilo da je i vjerodostojan, morao bi se razumjeti u svjetlu prvog hadisa radi kompromisa i usklađivanja njihovih, naizgled, oprečnih značenja, nakon čega bi se došlo do zaključka da se pronađene stvari minorne vrijednosti ipak trebaju oglašavati tri dana, jer se neograničena forma mutlak mora podvrći ograničenoj - mukajjed. ."36

Nevevi je rekao: „Pronađene stvari, minorne vrijednosti, je također dužnost - vadžib oglašavati sve dok se ne bude smatralo da ih njihovi vlasnici više ne traže. “37

c) Kada se onaj koji pronađe izgubljenu imovinu boji da će mu je oduzeti nadležni/nadređeni.

U tom slučaju ona ostaje kod njega kao emanet. Ovo mišljenje zastupaju šafijski pravnici. ${ }^{38}$

\section{Dužina oglašavanja pronađene imovine}

Naprijed citirani hadisi nalažu onome ko pronađe izgubljenu imovinu njen pronalazak oglašavati godinu dana. U hadisu kojeg prenosi Halid b. Zejd stoji da je Poslanik, a.s., rekao: „Oglašavaj je godinu dana!““ Hadis je muttefekun alejhi.

\footnotetext{
35 Ahmed, Musned, prenosi sa slabim lancem prenosilaca pod brojem: 16907, a neki smatraju da je dobar - hasen.

36 Ševkani, Nejlul-evtar, 5/337-338.

37 Nevevi, Šerhu Sahihi Muslim, 12/22, Ibn Abidin, Hašije, 6/436.

${ }^{38}$ Er-Remli, Nihajetul-muhtadž, 5/434.
} 
Ovaj rok oglašavanja pronađene imovine je prihvaćen konsenzusom islamskih učenjaka. Ibn Kudame je rekao: „Po ovom pitanju mi nisu poznata nikakva razilaženja među islamskim učenjacima. “39

Međutim, on se ne prihvata u sljedećim situacijama:

- kod pronađenih stvari s neznatnom vrijednosti. Njihov pronalazak će se, kako je naprijed i rečeno, oglašavati samo tri dana, ili nakon uvjerenje da su ih njihovi vlasnici prestali tražiti.

- kod pronađenih stvari koje su po prirodi brzo kvarljive poput voća, povrća, hrane itd. Njihov pronalazak će se oglašavati onoliko vremena za koliko se neće pokvariti ili isteći rok upotrebe. Ovo je mišljenje hanefijskih i hanbelijskih pravnika.

\section{Vrijeme i broj oglašavanja pronalaska izgubljene imovine}

$\mathrm{Za}$ oglašavanje treba izabrati najpogodnije vrijeme te oglašavati onoliko puta koliko je dovoljno da obavijest dopre do vlasnika izgubljene stvari. ${ }^{40}$

Ibn Hemmam je u tom smislu rekao: „Naredba oglašavanja pronađene stvari zahtijeva njegovo ponavljanje onoliko puta koliko to nalaže običaj i tradicija. Ukoliko bi se njen pronalazak oglasio na početku i na kraju godine, naredba oglašavanja bi se ispunila. Međutim, ispravnije je da se ona primijeni u svjetlu običaja i tradicije, stoga se to oglašavanje treba ponavljati s vremena na vrijeme i kad god se ukaže prilika za to. ${ }^{\text {‘4 }}$

Prema tome, obaveza je da se odmah po pronalasku izgubljene stvari, njen pronalazak razglasi sukladno običajima i tradiciji mjesta u kojem se oglašava i onoliko puta koliko se smatra da je dovoljno kako bi vijest mogla stići do njena vlasnika, a nije dozvoljeno odugovlačiti i odgađati to oglašavanje. ${ }^{42}$

\footnotetext{
39 Ibn Kudame, El-Mugni, 6/348, Ibn Hemmam, Fethul-Kadir, 6/114.

40 Ibn Kudame, El-Mugni, 6/349.

41 Ibn Hemmam, Fethul-Kadir, 6/115.

42 Ševkani, Nejlul-evtar, 5/340, Ibn Kudame, El-Mugni, 6/3 49 .
} 


\section{Mjesta na kojima treba oglašavati pronalazak izgubljene imovine}

Onaj koji pronađe izgubljenu imovinu njen pronalazak treba oglašavati na svim javnim mjestima sukladno običajima i sredstvima javnog informisanja, mjestima oglašavanja, a najbolje je na lokalitetu gdje je i pronađena. $^{43}$

Potom na mjestima gdje se ljudi okupljaju - pijacama, oglasnim tablama raznih institucija, džamijama, ${ }^{44}$ novinama, radiju, televiziji te ostalim printanim i elektronskim medijima.

\section{Ko oglašava pronalazak izgubljene stvari?}

Pronađenu stvar oglašava onaj koji je pronađe, ili njegov zamjenik, ili onaj koga on ovlasti. ${ }^{45}$ Uslovljava se da onaj ko oglašava pronalazak izgubljene stvari bude pametan, u protivnom oglašavanje neće biti validno pa će umjesto njega to učiniti njegov skrbnik. Ovo je mišljenje šafijskih pravnika. ${ }^{46}$ Isti je propis kad pronađenu stvar nađe mlađi maloljetnik, matuh i veliki grješnik, dok se oglašavanje od strane starijeg maloljetnika smatra validnim. ${ }^{47} \mathrm{U}$ savremenom dobu to je najbolje uraditi putem medija koji se bave time ili podržavaju te opcije sukladno običaju, vrsti imovine, situaciji i prilikama.

\section{Ko snosi troškove oglašavanja?}

Hanefijski i hanbelijski pravnici smatraju da troškove oglašavanje pronađene stvari snosi onaj ko je pronađe. ${ }^{48}$

Malikijski pravnici smatraju da ih snosi vlasnik izgubljene stvari. ${ }^{49}$

Šafijski pravnici prave razlike u nijetu onog ko je pronađe. Ko uzme izgubljenu imovinu s nijetom čuvanja sve dok se ne pronađe njen

\footnotetext{
43 Ševkani, Nejlul-evtar, 5/3 40 .

44 Ibn Hadžer, Fethul-Bari, 5/98, Nevevi, El - Medžmu', 6/145, Ibn Kudame, ElMugni, 6/ 349, Ibn Abidin, Hašije, 6/436.

45 Ševkani, Nejlul-evtar, 5/340.

46 Nevevi, El-Medžmu', 16/173.

${ }^{47}$ Nevevi, El-Medžmu', 16/175, Ibn Kudame, El-Mugni, 6/350.

48 Ibn Abidin, Hašije, 6/349.

49 Sehnun, El-Mudevveneh, 4/457.
} 
vlasnik, troškove će snositi bejtul-mal - država ili će se namiriti od same nađene imovine tako što će se prodati njen dio radi pokrivanja troškova oglašavanja. A ko je uzme s nijetom da je vrati vlasniku i ako se ne pojavi da je prisvoji sebi, u tom slučaju će troškove snositi onaj ko je nađe.

Ukoliko izgubljenu imovinu nađe dijete ili luđak njen pronalazak će oglašavati njihov staratelj. Troškovi oglašavanja se neće plaćati iz njihova imetka, nego će staratelj stvar predati nadležnima da prodaju njen dio, ili da radi oglašavanja uzme kredit na ime vlasnika izgubljene stvari. Ovo mišljenje zastupaju neki hanbelijski pravnici. ${ }^{50}$

Za vrijeme oglašavanja mogu se pretpostaviti dvije situacije:

a) Da se javi vlasnik pronađene imovine u vremenu koje je određeno za oglašavanje tj. u periodu od godinu dana.

b) Da prođe predviđeno vrijeme za oglašavanje, to jest, godina dana i da se on ne javi.

Ukoliko se on u roku od godinu dana pojavi i utvrdi da je vlasnik pronađene imovine, dužnost je da mu se ona i preda. Pri identifikaciji vlasništva nad njom dovoljno je od njega zatražiti samo da navede njene osobine, količinu, vrstu, boju itd. Isto tako, ne treba tražiti da se zaklinje zbog toga, jer se to u hadisu ne traži: „Ako ti neko dođe i potvrdi ti broj, oblik i vrpcu izgubljene stvari predaj mu je. ${ }^{\text {"51 }}$ Ukoliko se, nakon što pronalazač izgubljene stvari preda istu onome koji mu je tačno opisao, pojavi njen pravi vlasnik - on neće biti odgovoran za nju.

Njen pravi vlasnik u tom slučaju će imati pravo da je uzme od onoga koji ju je uzeo bespravno. Ovo je stav hanbelijskih, malikijskih i zahirijskih pravnika.

Hanefijski i šafijski pravnici smatraju da je onome koji tvrdi da je vlasnik izgubljene stvari nužno to i dokazati. ${ }^{52}$ Ovo mišljenje je prihvatljivije, jer je bliže duhu islama i njegovim intencijama, jer kada bi se pozitivno odgovaralo na sva potraživanja i tužbe ljudi jednih protiv

\footnotetext{
50 Eš-Šehri, Es-Selsebil, 2/599.

51 Nevevi, Šerhu Sahihi Muslim, 12/23, Ševkani, Nejlul-evtar, 5/324, San'ani, Subulus-selam, 3/117.

52 Ibn Hemmam, Fethul-Kadir, 6/121, Nevevi, El-Medžmu', 16/154.
} 
drugih, imovina ljudi, općenito bi bila ugrožena od bespravna oduzimanja i uzurpacije. Bila bi također, nezaštićena i izložena uništenju što je oprečno osnovnim univerzalnim ciljevima o zaštiti imovine.

Ukoliko se nakon godinu dana ne pojavi vlasnik izgubljene stvari, ona će preći u vlasništvo onoga koji ju je našao - svejedno bio bogat ili siromah. Nasljeđivat će se kao i sva ostala njegova imovina.

Ovo mišljenje se temelji na hadisu kojeg prenosi Zejd b. Halid da je Allahov Poslanik, a.s., rekao: „Ona je, to jest, izgubljena stvar kao i tvoj imetak.“ U drugoj predaji stoji: „Pomiješaj je sa svojim imetkom!““

U trećoj predaji se kaže: „Koristi se njome!“ Očito je da citirane predaje imaju slična značenja. Ibn Hadžer je rekao: „Naredbe u navedenim predajama aludiraju na mubah - dozvoljenost, a ne obligaciju, stoga je dovoljan samo nijet pa da izgubljena stvar pređe u tvoje vlasništvo, i ovo je najjači dokaz." ${ }^{53}$

Ukoliko bi se nakon godinu dana pojavio vlasnik izgubljene imovine, neki islamski pravnici smatraju da mu se ona mora vratiti ili kompenzirati ako je pronalazač živ, u protivnom će to uraditi njegovi nasljednici. Ovo je stav šafijske i hanbelijske pravne škole.

Malikijska pravna škola smatra da je u navedenom slučaju dozvoljeno prisvojiti izgubljenu stvar ako je njen pronalazač siromašan. U protivnom će je podijeliti u sadaku, a dozvoljeno mu je zadržati i za sebe. $^{54}$

Hanefijska pravna škola smatra da, ukoliko njen pronalazač bude siromašan, dozvoljeno mu je prisvojiti je, u protivnom nije, pa će je morati podijeliti u sadaku. ${ }^{55}$

Smatramo da je obaveza predati nađenu stvar njenu vlasniku ukoliko se pojavi u periodu koji je određen za oglašavanje, u protivnom, nađenu stvari je preče podijeliti u sadaku na ime njena vlasnika ukoliko

53 Ibn Hadžer, Fethul-Bari, 5/99-101, Nevevi, Šerhu Sahihi Muslim, 12/23, San'ani, Subulus-selam, 3/118.

54 Sehnun, El-Mudevvene, 4/455, Ibn Rušd, Bidajetul-mudžtehid, 2/229.

55 Ibn Abidin, Hašije, 6/438, San'ani, Subulus-selam, 3/118, Ibn Rušd, Bidajetul mudžtehid, 2/292. 
pronalazač nije siromašan, a može je zadržati i za sebe. Isto tako, ukoliko se njen vlasnik pojavi poslije godinu dana, bilo bi preporučeno, bolje i bliže duhu i intencijama islama, da mu se njegovo pravo preda ako je to moguće, ali bez nanošenja štete pronalazaču, jer princip zastarijevanja ne može biti legalan i legitiman razlog bogaćenja i stjecanja imovine $u$ islamu zbog neotuđivosti tuđih prava.

\section{Kompenzacija nestanka ili uništenja pronađene imovine}

Pronađena imovina ima status emaneta kod onog koji je nađe. Obaveznost njene materijalne kompenzacije islamski pravnici su posmatrali na osnovu nijeta - namjere koju je pronalazač imao kod njena pronalaska. $\mathrm{Na}$ osnovu toga se mogu pretpostaviti sljedeće situacije:

a) Ko je uzme s nijetom čuvanja i vraćanja vlasniku, imat će status emaneta pa se neće za njeno uništenje ili nestanak plaćati nikakva materijalna protuvrijednost, osim ako se namjerno uništi, ili ne bude čuvala kako to nalaže običaj i tradicija. ${ }^{56}$

b) Ako bude uzeta s nijetom prisvajanja i nevraćanja njenom vlasniku, pronalazač će u tom slučaju biti odgovoran za nju, jer ima status otete stvari pa će se nad njom primijeniti propisi iste. Ovo mišljenje zastupa većina islamskih pravnika. ${ }^{57}$

Nijet će se utvrđivati na priznanju pronalazača i vjerovanja u njegove tvrdnje. Ovo mišljenje zastupa Ebu Hanife i Ebu Jusuf. ${ }^{58}$

Ukoliko se pronađena stvar uništi pa nakon toga dođe vlasnik i povjeruje pronalazaču da ju je uzeo s nijetom njena čuvanja i vraćanja, on neće biti obavezan plaćati njenu protuvrijednost, zato što se njen status emaneta prihvatio od strane vlasnika na osnovu tvrdnje pronalazača.

Ako vlasnik nađene stvari ne povjeruje u tvrdnje pronalazača koji je pri njenom pronalasku pred svjedocima potvrdio da ju je uzeo s nijetom

\footnotetext{
56 Ibn Kudame, El-Mugni, 6/361, Ševkani, Nejlul-evtar, 5/434, Nevevi, Šerhu Sahih Muslim, 12/24.

57 Ibn Kudame, El-Mugni, 6/361, Ibn Hemmam, Fethul-Kadir, 6/112.

58 Ibn Hemmam, Fethul-Kadir, 6/112.
} 
čuvanja i povrata vlasniku, neće biti obavezan da je kompenzira, jer je njegova tvrdnja potvrđena svjedocima.

Ukoliko svoju namjeru o čuvanju ne bude verifikovao pred svjedocima, onda bi se morao zakleti da mu je namjera od njena preuzimanja bila samo njeno čuvanje i vraćanje vlasniku. Njegova tvrdnja bi se u tom slučaju prihvatila zbog toga što se, u osnovi islamskog sudstva prihvata tvrdnja onog koji dokazuje status nekog emaneta s tim što se mora još i zakleti.

Ovo mišljenje zastupaju Ebu Jusuf, malikijski, šafijski i hanbelijski pravnici.

c) Ukoliko neko uzme izgubljenu imovinu s nijetom njena čuvanja i vraćanja njenom vlasniku, pa je potom vrati na mjesto gdje ju je pronašao i ona nakon toga nestane, hanefijski i malikijski pravnici smatraju da on neće snositi posljedice njena nestanka. ${ }^{59}$

Šafijski i hanbelijski pravnici smatraju da hoće, jer je nađena stvar nakon njena preuzimanja dobila status emaneta, a emanet se mora čuvati i paziti. ${ }^{60}$

Mišljenje koje zastupaju šafijski i hanbelijski pravnici je prihvatljivije jer se njegovom primjenom štite imovinska prava ljudi, a pravni sistem i međuljudski odnosi postavljaju na čvršće, stabilnije i ozbiljnije temelje.

\section{Drugi dio: Pravni status izgubljenih životinja}

Izgubljene životinje u islamskom pravu se nazivaju dalleh, a ostala izgubljena imovina, kako je rečeno, lukata, a likit je termin za ostavljeno dijete - nahoče. ${ }^{61}$

Izgubljene životinje se mogu svrstati u dvije vrste:

- krupna stoka poput: deva, krava, konja itd.

\footnotetext{
59 Ibn Abidin, Hašije, 6/435, Dusuki, Hašije, 3/121.

60 Merdavi, El-Insaf, 6/421, Remli, Nihajetul-muhtadž, 5/435, Nevevi, El-Medžmu', 16/158, Ibn Kudame, El-Mugni, 6/368.

${ }^{61}$ San'ani, Subulus-selam, 3/117, Ibn Hadžer, Fethul-Bari, 5/99, Nevevi, Šerhu Sahihi Muslim, 12/21.
} 
- sitna stoka poput ovaca, koza, peradi itd.

Krupna stoka se odlikuje sljedećim osobinama:

- može se prehraniti i spasiti od smrti i

- sama se braniti od sitnih zvijeri svojom urođenom snagom koju im je Allah podario.

Sitna stoka - suprotno navedenom.

\section{Hvatanje i zatvaranje izgubljenih životinja}

Islamski pravnici su zauzeli različite stavove oko hvatanja i zatvaranja izgubljenih životinja.

Hanefijski pravnici ne prave razliku između izgubljenih stvari i izgubljenih životinja. Propisi koji se odnose na izgubljene stvari kod njih su isti i važe i za izgubljene životinje. Oni dozvoljavaju hvatanje izgubljenih životinja kao i uzimanje izgubljenih stvari radi zaštite tuđe imovina od uništenja, što je opća obaveza svih onih koji su to $u$ mogućnosti. ${ }^{62}$

Malikijski, šafijski i hanbelijski pravnici smatraju da nije dozvoljeno uhvatiti i zatvoriti izgubljene životinje na osnovu hadisa kojeg prenosi Zejd b. Haris po kom se zabranjuje hvatanje i zatvaranje izgubljenih životinja, jer su sposobne da se same brane $\mathrm{i}$ hrane.

Međutim, neki pravnici su mišljenja da se spomenuta zabrana u hadisu odnosi samo na one koji njihovim hvatanjem i zatvaranjem namjeravaju njihovo prisvajanje, a ne i čuvanje. Prema tome, dozvoljeno ih je uhvatiti i zatvoriti radi zaštite, čuvanja i vraćanja njihovom vlasniku. Ovo je mišljenje nekih šafijskih pravnika. ${ }^{63}$

Neki pravnici smatraju da je zabranjeno uhvatiti i zatvoriti samo izgubljene deve ali ne i ostale hajvane i životinje, jer se u hadisu kojeg prenosi Zejd b. Haris kaže: „Šta ti imaš s njima - devama? One sa

\footnotetext{
${ }^{62}$ Marginani, El-Hidaje, 2/471.

63 Ibn Hadžer, Fethul-Bari, 5/96.
} 
sobom imaju odbranu i opskrbu. Same idu na vodu i same se hrane lišćem, pa ih pusti sve dok ih ne pronađe njihov vlasnik. “64

Većina islamskih učenjaka su, analogno na deve, zabranili hvatanje i zatvaranje svih izgubljenih životinja koje se mogu same hraniti i braniti od manjih zvijeri. ${ }^{65}$

Također, smatraju da je dozvoljeno nadležnima uhvatiti i zatvoriti izgubljene životinje kada za to postoji opravdana potreba ili nužda kao, naprimjer, kada se boje da će ih neko ukrasti, prisvojiti, da će ih zvijeri pojesti i sl. ili kada među ljudima nestane povjerenja i poštenja. U ovakvim situacijama ako bi ih neko mimo odgovornih uhvatio i zatvorio, dužnost bi mu bila predati ih nadležnim vlastima.

Obavezno je hvatanja izgubljenih životinja i onda kada postoji opravdana bojaznost i opasnost od ugrožavanja ljudskih života i imovine. U tom slučaju njihovo hvatanje i zatvaranje je obaveza radi zaštite ljudskih života i imovine - osnovnih univerzalnih ljudskih vrijednosti koje moraju biti zaštićene u islamskom društvu i državi.

Dozvoljeno je, također, hvatanje i zatvaranje sitne stoke, jer se u hadisu kojeg prenosi Zejd b. Halid jasno kaže: „Uhvatite ih (tj. ovce), jer će pripasti tebi, tvom bratu ili vuku." 66

Islamski učenjaci su, na osnovu analogije na ovce, dozvolili hvatanje i zatvaranje sve sitne stoke koja samu sebe ne može zaštiti, niti prehraniti. ${ }^{67}$

Na ostale izgubljene životinje poput kućnih ljubimaca: pasa, mačaka, raznih vrsta ptica itd. će se odnositi isti propisi koji važe za stoku ukoliko imaju neku vrijednost po šerijatu, jer će na taj način dobiti status imovine $\mathrm{u}$ islamu. U protivnom će se smatrati bezvrijednim stvarima na koje se neće odnositi navedeni propisi.

\footnotetext{
${ }^{64}$ Ibn Hadžer, Fethu-Bari, 5/96, Nevevi, Šerhu Sahihi Muslim, 9/126.

65 Ševkani, Nejlul-evtar, 5/345, Ibn Hadžer, Fethul-Bari, 5/97.

${ }^{66}$ Buhari, Sahih, br. hadisa 2427, Muslim, Sahih, br. hadisa 1722.

${ }^{67}$ Ibn Kudame, El-Mugni, 6/3 ${ }^{90 .}$
} 


\section{Najpoznatiji propisi koji tretiraju izgubljene životinje}

Islamski pravnici su do u detalje razradili propise koji tretiraju ovo pitanje. Mi ćemo ih sukladno prostoru, vremenu i zadatoj temi sublimirati i navesti najvažnije od kojih su:

1. - Nije dozvoljeno da se hvataju deve, a analogno tome ni sva ostala krupna stoka. Ovo je mišljenje većine islamskih pravnika. Opravdavaju ga činjenicom da je u njihovom nehvatanju i nezatvaranju veća mogućnost pronalaska od strane vlasnika, te da se one mogu same zaštiti i hraniti. ${ }^{68}$

Međutim, ovo mišljenje se može primijeniti u pustinjama i savanama, ali ne može u poljima i privatnim posjedima gdje jedno hajvanče za kratko vrijeme može uništiti cijelo polje poljoprivrednih usjeva. Prema tome, u ovakvim podnebljima je nužno da se krupna stoka uhvati, zatvori i oglasi njen pronalazak. Ne smije se ostavljati da uništava tuđu imovinu.

2. - Nadležni imaju pravo da uhvate i zatvore krupnu stoku ukoliko se boje za opći interes i tuđu imovinu, ili s namjerom da je zaštite i vrate njihovim vlasnicima. Oni nisu obavezni oglašavati njen pronalazak. ${ }^{69}$

3. - Vlasti bi trebale odrediti mjesto za sakupljanje i izdržavanje izgubljene stoke sve dok je njeni vlasnici ne pronađu. Ukoliko zaključe da je veća korist prodati je i njenu protuvrijednost sačuvati njihovim vlasnicima ako se pojave, dozvoljeno im je to uraditi. ${ }^{70}$

4. - Ukoliko izgubljenu stoku uhvati i zatvori neko drugi mimo vlasti, snosit će posljedice njena nestanka. Odgovornosti bi se spasio samo ako bi je vratio njenom vlasniku. Ako bi je vratio na mjesto gdje ju je pronašao, ne bi se oslobodio odgovornosti, niti bi je smio prisvojiti sebi nakon što prođe godina dana od njena pronalaska i zatvaranja, ako se ne pojavi njen vlasnik. ${ }^{71}$

\footnotetext{
${ }^{68}$ Ibn Hadžer, Fethul-Bari, 5/97, Ibn Dekik El-'Id, Ihkamul-ahkam, 2/160.

69 Nevevi, El-Medžmu', 6/158, Ibn Kudame, El-Mugni, 6/398, Ševkani, Nejlul-evtar, $5 / 345$.

70 Ibn Kudame, El-Mugni, 6/399.

71 Ibn Kudame, El-Mugni, 6/398.
} 
5. - Ukoliko bi neko tvrdio da je vlasnik izgubljene životinje, svoju tvrdnju bi morao potkrijepiti dokazima, jer pri identifikaciji njihova vlasnika nije dovoljno navesti samo osobine i specifičnosti životinje, zbog toga što je stoka bila vidljiva svakome prije njena hvatanja i zatvaranja.

6. - Za razliku od krupne stoke, sitnu stoku je dozvoljeno uhvatiti i zatvoriti iz bojazni da se ne izgubi ili bude uništena. U protivnom bi se svjesno dozvolilo uništenje tuđe imovine što je po islamu zabranjeno. ${ }^{72}$ 7. - Ko uhvati i zatvori sitnu stoku ima tri izbora:

a) da je zakolje i pojede, ili da rasproda njeno meso pod uvjetom da kompenzira vlasniku njenu vrijednost ako se pojavi. Ovo je mišljenje sve četiri pravne škole. Malikijski pravnici dozvoljavaju pronalazaču da je zakolje i konzumira njeno meso, ali mu zabranjuju da je proda $\mathrm{i}$ okoristi se tim novcem. Međutim, prvo mišljenje se preferira. ${ }^{73}$

b) da je proda pa sačuva njenu vrijednost vlasniku kada se pojavi i dokaže da je njegova. ${ }^{74}$

c) da je hrani i čuva sve dok se ne pojavi njen vlasnik, pod uvjetom da je sebi ne prisvoji. Troškovi koje uloži za njeno izdržavanje imat će status dobrovoljnih priloga - sadake po mišljenju šafijskih i hanbelijskih pravnika, te po drugom mišljenju malikijskih. ${ }^{75}$

8. - Ako pronađena životinja ugine kod pronalazača, odgovornost će on snositi po većini islamskih pravnika. ${ }^{76}$

Šafijski pravnici smatraju da neće, jer pronađena životinja po njima ima status emaneta. Hanbelijski pravnici kažu da životinja ukoliko ugine zbog toga što je pronalazač nije dovoljno pazio, da će on biti odgovoran. U protivnom, neće. ${ }^{77}$

\footnotetext{
72 Ibn Dekik El-'Id, Ihkamul-ahkam, 2/160.

73 Ibn Hadžer, Fethul-Bari, 5/99.

74 Ibn Kudame, El-Mugni, 6/392-394.

75 Nevevi, El-Medžmu', 16/159, Ibn Kudame, El-Mugni, 6/394.

${ }^{76}$ Ibn Hadžer, Fethul-Bari, 5/102.

${ }^{77}$ Nevevi, El-Medžmu', 16/19, Ibn Kudame, El-Mugni, 6/395.
} 
9. - Većina islamskih pravnika smatra da je pronalazač sitne stoke obavezan oglašavati njen pronalazak godinu dana. Imam Malik smatra da on to uopće nije obavezan. ${ }^{78}$

\section{Status produkata i koristi koje nastanu od izgubljenih I pronađenih životinja}

Oni se mogu podijeliti na dvije vrste:

1. - Poboljšanja koja nastanu na samoj životinji poput debljanja, oporavka, ozdravljenje itd. Svi navedeni i slični benefiti pripadaju njenom vlasniku kada je pronađe.

2. - Produkti ili koristi koji se odvoje od životinje poput mladunčadi, mlijeka, mliječnih proizvoda itd. Ukoliko životinja koja se pronađe bude imala sa sobom mladunče, ono pripada vlasniku životinje. Međutim, ukoliko se ona oteli ili ojanji kod pronalazača, mladunče će pripast njemu, jer se rodilo kod njega pa njemu i pripada. ${ }^{79}$ Što se tiče ostalih proizvoda poput mlijeka i njegovih proizvoda, po najispravnijem mišljenju će pripasti onima koji pronađene životinje budu hranili i čuvali na osnovu pravila el-magnemu bil-magremi - uz dobiti ide i šteta, kao kompenzacija za troškove i trud koji čine prema takvim životinjama.

\section{Umjesto zaključka}

Studija je dovela do sljedećih rezultata:

- Imovina je univerzalna vrijednost u islamu, stoga je zaštićena u svim prilikama i situacijama.

- Vlasništvom nad njom se ne gubi s njenim gubljenjem ili zastarijevanjem.

- Javna i privatna imovina u islamu je jednako tretirana i ne preferira se jedna nad drugom u normalnim uvjetima.

\footnotetext{
${ }^{78}$ Nevevi, El-Medžmu', 16/159, Ibn Kudame, El-Mugni, 6/390, Nevevi, Šerhu Sahihi Muslim,12/23, Ibn Hadžer, Fethul-Bari, 5/99.

${ }^{79}$ Nevevi, El-Medžmu', 16/151, Ibn Hadžer, Fethul-Bari, 5/120, Nevevi, Šerhu Sahihi Muslim, 12/22. Vidi o ovoj temi: Zejdan, El-Lukata ve ahkamuha fiš-šeri'atilislamijje.
} 
- U nemogućnosti njihova tretiranja daje se prednost javnoj imovini pod uvjetom da se privatna pravedno kompenzira po tržišnim vrijednostima.

- Islam je jasno definirao principe pod kojima se imovina, kako javna, tako i privatna, smije stjecati, investirati i trošiti.

- Svako odstupanje od navedenih principa čini ih nelegalnim haram. Za to slijede ovosvjetske sankcije i onosvjetske kazne.

- Bespravno uzurpiranje i uništenje, kako javne, tako i privatne imovine u islamu je strogo zabranjeno.

- Izgubljena imovina u islamu podliježe navedenim pravilima i principima koja su islamski pravnici detaljno pojasnili i ustanovili. Oni se moraju poštivati kod tretiranja takve vrste imovine.

- Svi ti principi imaju istu intenciju - da zaštite privatno i javno vlasništvo od njegova propadanja i bespravne uzurpacije i uništenja bilo koje vrste.

- Njihovo ignoriranje je po islamu zabranjeno i ima za posljedicu bespravno bogaćenje, širenje nereda, nasilja i nepravde na Zemlji, a sve to Zakonodavac ne voli i najstrožije kažnjava kako na ovom tako i na onom svijetu.

\section{Korištena literatura}

1. Ibn Hadžer, Fethul-Bari bi šerhi Sahihil-Buhari, terkim: Muhammed Fuad Abdul-Baki, el-Matbe'atus-selefijje.

2. Ibn Hazm, El-Muhalla, tahkik: Muhammed Šakir, Darut-turas, bez godine izdanja. Dusuki, Hašijetud-Dusuki alaš-Šerhil-kebir lid-Derdir, Matbe'atu Isa El-Halebi, bez godine izdanja.

3. Ibn Dekik El-'Id, Ihkamul-ahkam, Šerhu 'Umdetil-ahkami, Darulkutubil-'ilmijje, Bejrut, Liban, bez godine izdanja.

4. Remli, (1386) Nihajetul-muhtadž Šerhul-Minhadž, Matbe'atu Mustafa el-Halebi

5. Ibn Rušd, (1401. po H.) Bidajetul-mudžtehid ve nihajetul-muktesid, musavvere 'an matbe'ati Mustafa el-Halebi, Bejrut.

6. San'ani, Subulus-selam šerhu Bulugil-meram min džem'i edilletil-ahkam, Darul-furkan, Amman, Jordan, bez godine izdanja. 
7. Sehnun, El-Mudevveneh, rivajetu Sehnun, Daru sadir, Bejrut, 'an Matbe'atis-se'ade.

8. Ševkani, Nejlul-evtar min ehadisi sejjidil-ahbar Šerhu Muntekil-ahjar, Darul-kalem Bejrut, bez godine izdanja.

9. Šehri, Muhammed Abdurrahaman b. Ali, Es-Selsebil šerhu Kasdis-sebil fil-džem'i bejnez-zadi ved-delili, remzul-muntidži: bmsk12709, tasnifati: el-fkhul-islami, el-kutubul-matbu'a, el-vesm: el-fikhul-hanbeli, PDF.

10. Abdul-Kerima, Zejdan (1988) El-Lukata ve ahakamuha fiš-šeri'atilislamijje, El-Muessesetur-risaleh, es-silselitu medžmu'atin buhusin fikhijjetin.

11. Ibn Abidin (1386. po H.) Hašije reddil-muhtari 'aled-Derril-muhtari, Matbe'atu Mustafa El-Halebi.

12. Ibn Abdulberr, (1421/2000) El-Istizkar el-džami'u limezahibi fukahailemsar ve ulemail-aktar, Darul-kutubil-ilmijje, et-tab'atul-ula, Bejrut.

13. Ibn Kudame, (1405. po H.) El-Mugni, šerhu Muhtesaril-Hirki ve m'ahu Eš-Šerhul-kebir, Darul-fikr, Bejrut.

14. Marginani, El-Hidaje šerhu Bidajetil-mubtedi, Darul-kutubil-ilmijje, Bejrut, Liban

15. Merdavi, (1400. po H.) El-Insaf fi m'arifetir-radžihi minel-hilafi, Daru ihjait-turasil-arabijji, Bejrut.

16. Nevevi, (1405. po H.) Revdatut-talibin, El-Mektebul-islami, Damask

17. Nevevi, El-Medžmu', šerhul-Muhezzebi me'a tekmiletis-Subki vel-Muti'i, Matbe'ul-imami ve matbe'atul-asime.

18. Nevevi, (1981) Šerhu Sahihi Muslim, Darul-fikr, Bejrut, Liban.

19. Ibn Hemmam, Šerhu Fethul-Kadir alel-Hidaje, Darul-fikr, Bejrut, Liban, drugo izdanje, bez godine izdanja. 
dr. sci. Sulejman Topoljak, full professor

University of Bihać

Islamic Pedagogical Faculty

Email: sulejman.topoljak@hotmail.com

\section{LEGAL STATUS OF LOST PROPERTY IN ISLAM}

\section{Summary}

This study, within the established rules of scientific elaboration, seeks to explore two basic goals. The first is to implicitly emphasize the universality and consistency of Islamic law, the main feature of which is its foundation on ethics and morality, the principles of which it protects with its legal norms and sanctions. And the second goal is to emphasize in the same way the importance and protection of property in Islam, according to which it is not the goal or the main value in human life, but only a means that must be possessed and used in realizing the system of priorities and basic goals for which Allah created man. in this cosmos.

According to the philosophy of Islam, all people are brothers, so they have the same right to natural resources as well as human dignity, so they are obliged to protect buman values and the cosmic system set up by God, and to oppose all those who violate and devalue these principles. , or ignore and destroy them. The philosophy of property in Islam defines the perception and vision of its intention in the lives of Muslims. It is the exact opposite of the same in modern

ideology, so their various consequences on life and people's relations with it, as well as on interpersonal relations in general, are inevitable. One who does not know this can neither understand nor comprehend two opposing civilizations that originated from two different philosophies of life.

Keywords: property, lost property, objects, animals, regulations, law schools, madhhabs, lawyers 
الأستاذ الدكتور سليمان توبولياك

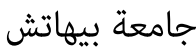
كلية التربية الإسلامية

\section{حكم الممتلكات المفقودة في الإسلام}

\section{الخلاصة}

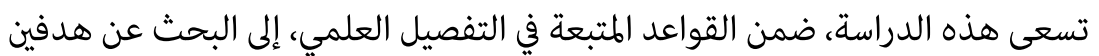

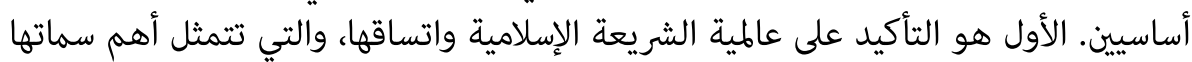

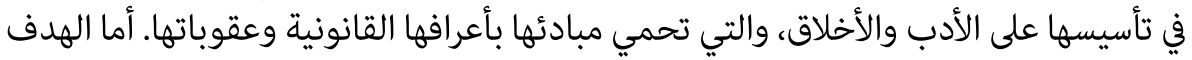

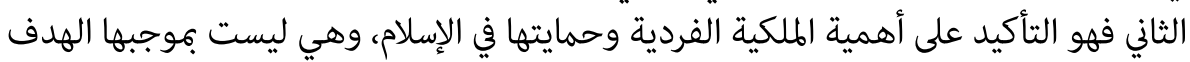

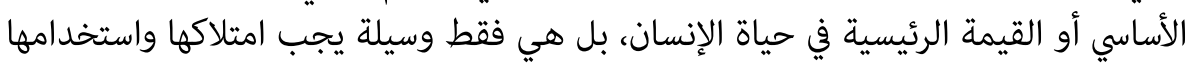
في ترتيب الأولويات وتحقيق الأهداف الأساسية التي من أجلئية الجلها خلق القان الله الإنسان في هذا

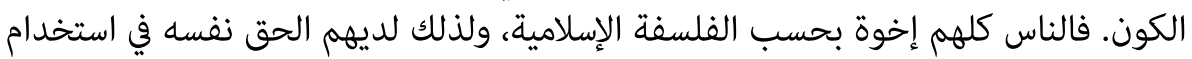

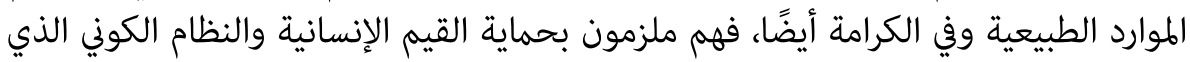

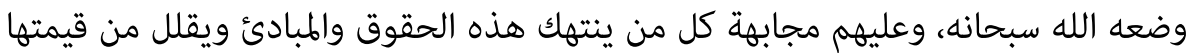

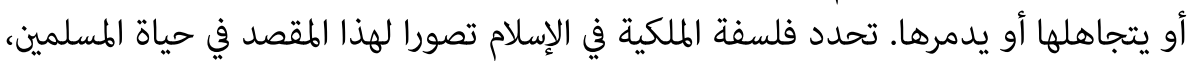

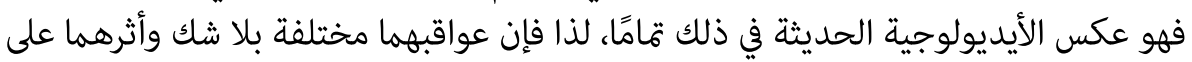

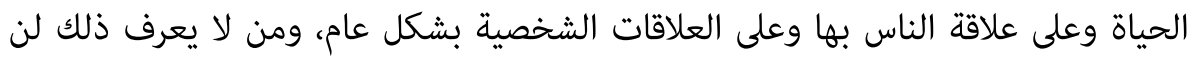

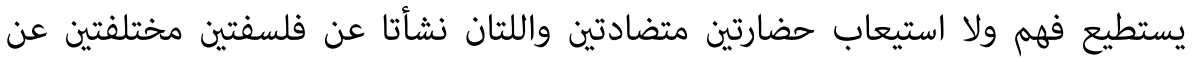
الحياة.

الكلمات المفتاحية: الممتلكات، الممتلكات المفقودة، الأشياء، الحيوانات، الأحكام، الفهاء المدارس الفقهية، المذاهب، الفقهاء. 